\title{
PERANCANGAN ULANG \\ HEADSET DAN PENUTUP MATA UNTUK TIDUR \\ MENGGUNAKAN METODE NIGEL CROSS
}

Gentha Oryza Dharma ${ }^{1}$, Dyah Rachmawati Lucitasari. ${ }^{2}$, Muhammad Shodiq Abdul Khannan. ${ }^{2}$

1. Alumni Jurusan Teknik Industri 2. Dosen Jurusan Teknik Industri

Jurusan Teknik Industri Fakultas Teknik Industri

Universitas pembangunan Nasional "Veteran" Yogyakarta

Jl. Babarsari 2 Tambakbayan, Yogyakarta, 55281

email : dyah.rachmawati@upnyk.ac.id, shodiq@upnyk.ac.id

\begin{abstract}
ABSTRAK
Tidur adalah kebutuhan semua manusia, dan tidur nyenyak sangat dibutuhkan agar kondisi tubuh prima. Memperoleh tidur yang cukup sangatlah penting karena jika seseorang selalu mendapatkan jam tidur yang kurang, akan sangat mempengaruhi kondisi kesehatan. Penelitian menunjukkan bahwa kurang tidur dapat menyebabkan masalah pada berat badan, kemurungan, masalah pada jantung dan bahkan membuat tubuh rentan terkena penyakit. Kebanyakan orang mengetahui bahwa tidur sangatlah penting, namun justru semakin hari semakin mendapatkan jam tidurnya berkurang karena berbagai alasan antara lain pekerjaan yang banyak, karena kurang nyamannya lingkungan sekitar dan saat berpergian.

Dari permasalahan di atas terlihat adanya kebutuhan headset dan penutup mata tidur yang lebih praktis untuk digunakan. Perancangan ulang headset dan penutup mata tidur ini akan dilakukan dengan menggunakan metode Nigel Cross sesuai dengan kebutuhan konsumen. Pengembangan desain ini diawali dengan mengklasifikasikan tujuan-tujuan dari perancangan dan menetapkan fungsi serta batasan sistem. Setelah itu menyusun kebutuhan konsumen untuk membuat spesifikasi alat yang baru, kemudian menetapkan karakteristik produk atau target apa yang akan dicapai sehingga sesuai dengan kebutuhan konsumen. Selanjutnya pembangkitan alternatif dari alat headset dan penutup mata untuk tidur desain baru, kemudian akan dievaluasi untuk dipilih mana yang terbaik untuk diproduksi.

Hasil penelitian menunjukkan bahwa alat headset dan penutup mata untuk tidur yang baru dapat diterima oleh konsumen, berdasarkan survey akhir, menunjukkan 95\% konsumen tidur lebih cepat dibandingkan dengan alat yang lama, $85 \%$ responden menyatakan puas dan merasa alat sesuai dengan harapan dan $75 \%$ bersedia membeli alat headset dan penutup mata untuk tidur yang baru.
\end{abstract}

Kata kunci : Headset dan penutup mata untuk tidur, headset, Nigel Cross.

\section{ABSTRACT}

Sleep is a need for all human being, and having sufficient sleep is a must to have a good condition. Research showed that lack of sleep will cause problem for increasing amount of body weight, bad mood, heart problem and indeed make the body susceptible to illness. Most people knows that sleep is very important, but they found their time of sleep decreases because of multiple reason for example is too many task, unpleasant surroundings area and travelling.

According to the ilustration above, there is a presence on the need of headset and eye masks for sleep that simple to use. Re-design headset and eye masks for sleep will be done using Nigel Cross approach model. This design development begins by classifying the goals of the design and assign function and system boundaries. After that compile costumer needs to make the spesification of the new design, then specify the characteristics that aims to determine which target to be achieved that conform with thr customer needs. Then, These alternatives be evaluated to choose which is the best to produce.

The results of a study showed that the headset and eye masks for sleep that are designed had been accepted by customer. Based on the final survey, showed $95 \%$ of customer said they sleep faster with headset and eye masks for sleep development results. $85 \%$ customer were satisfied and $75 \%$ willing to buy a headset and eye masks for sleep development results.

Keywords : Headset and eye masks for sleep, headset, Nigel Cross 


\section{PENDAHULUAN}

Seiring dengan perkembangan zaman yang semakin maju banyak tersedia headset maupun penutup mata untuk tidur di pasaran untuk memenuhi kebutuhan konsumen agar bisa istirahat tanpa terganggu oleh pengaruh dari luar seperti cahaya dan kebisingan, headset dan penutup mata yang tersedia di pasaran memiliki berbagai bentuk dan fungsi.

Headset dan penutup mata ini sangat berfungsi bagi banyak orang terutama bagi orang yang sensitif dengan suara dan cahaya, dengan memakai headset dan penutup mata biasanya konsumen bisa mengurangi suara dan cahaya yang berada disekitar lingkungannya, dan ada juga sebagian orang yang justru akan lebih suka tidur dengan mendengarkan musik terlebih dahulu yang juga bisa ditemukan pada headset yang memiliki speaker di dalamnya.

Untuk mengurangi kebisingan dan intensitas cahaya sekitar pada saat tidur, orang biasanya akan menggunakan headset dan penutup mata pada saat tidur. Namun akibat guncangan dan banyaknya gerakan akan membuat headset dan penutup mata bergeser atau terlepas dari kepala yang akan mengganggu tidur. Belum lagi headset tidur yang tersedia tidak memiliki speaker untuk memutar musik dan sangat tidak praktis untuk dipakai pada saat tidur.

Dari permasalahan di atas terlihat adanya kebutuhan headset dan penutup mata tidur yang lebih praktis untuk digunakan. Perancangan ulang headset dan penutup mata tidur ini akan dikaji dengan menggunakan metode Nigel Cross sesuai dengan kebutuhan konsumen. Metode Nigel Cross bisa menjadi metode alternatif selain metode Quality Function Deployment seperti yang digunakan Khannan (2010).

\section{LANDASAN TEORI}

\subsection{Pengertian Produk}

Produk adalah sebuah barang atau jasa yang dapat diperjual belikan, produk juga memiliki arti berupa apapun yang bisa ditawarkan ke pasar yang bisa memberikan kepuasan dari sebuah keinginan dan kebutuhan. Menurut Ulrich (2000), produk adalah "artefak" sesuatu yang merupakan hasil dari kreativitas manusia yang dapat dilihat, didengarkan, dirasakan, serta diwujudkan untuk memenuhi kebutuhan fungsional. Dalam pembuatan suatu produk diperlukan serangkaian perencanaan, perancangan dan pengembangan produk yang dimulai dari ide, dilanjutkan dengan tahapan pengembangan konsep, perancangan sistem secara detail, pembuatan prototipe, evaluasi dan pengujian.

\subsection{Perancangan dan Pengembangan \\ Produk}

Palgunadi (2008) menyatakan dalam perancangan dan pengembangan produk diperlukan beberapa langkah guna mempermudah pelaksanaan pembuatan produk, langkah-langkah tersebut adalah sebagai berikut :

1. Desain

Desain merupakan langkah awal perencanaan pembuatan produk yang memiliki output berupa sketsa gambar suatu produk yang akan dibuat.

2. Manufacturing

Manufacturing merupakan bagian dalam produksi terutama untuk menentukan langkah-langkah yang diperlukan untuk pembuatan produk.

3. Perencanaan bahan

Perencanaan bahan merupakan perencanaan yang berhubungan dengan bahan-bahan produksi yang akan digunakan untuk pembuatan produk

4. Perencanaan biaya

Perencanaan biaya merupakan suatu langkah memperkirakan seberapa besar biaya yang akan dikeluarkan dalam pembuatan suatu produk.

\subsection{Tolak Ukur Produk yang Berhasil}

Berikut ini adalah lima dimensi spesifik yang biasa digunakan untuk menilai berhasil tidaknya pengembangan produk menurut Ulrich (2001) yaitu:

1. Kualitas produk

Seberapa baik produk yang dihasilkan dari usaha pengembangan produk. Kualitas produk menjadi pengaruh yang cukup kuat dalarn pasar serta menjadi faktor yang menentukan harga yang ingin dibayar konsumen untuk produk yang dibuat.

2. Biaya produk

Biaya yang dimaksud adalah biaya yang digunakan untuk modal peralatan dan alat bantu serta biaya produksi 
setiap unit produk. Biaya produk ini menentukan besar laba yang dihasilkan.

3. Waktu pengembangan produk

Waktu pengembangan menentukan kemampuan berkompetisi, tanggapan akan perubahan teknologi, dan kecepatan untuk menerima pengembalian ekonomis dari usaha pengembangan produk.

4. Biaya pengembangan

Berapa biaya yang dikeluarkan untuk mengembangkan produk. Biaya pengembangan merupakan bagian penting yang berhubungan dengan laba.

5. Kemampuan pengembangan

Kemampuan pengembangan merupakan modal yang dapat digunakan untuk mengembangkan produk dengan lebih efektif dan ekonomis di masa yang akan datang.

\subsection{Metode Nigel Cross}

Perancangan produk menurut Cross terbagi atas tujuh langkah yang mempunyai yang masing-masing mempunyai metode tersendiri, yaitu:

1. Klarifikasi Tujuan

Langkah pertama yang penting dalam merancang adalah berupaya untuk memperjelas tujuan perancangan. Pada kenyataannya, sangat membantu dalam hasil di setiap langkah hingga hasil sesuai yang diharapkan. Akhir dari klarifikasi tujuan ini adalah sekumpulan tujuan perancangan objek yang harus dibuat walaupun tujuan-tujuan yang dibuat itu mungkin saja berubah dalam proses perancangan berikutnya.

Metode pohon tujuan memberikan bentuk dan penjelasan dari pernyataan tujuan. Metode ini menunjukkan tujuan dan sasaran yang akan dicapai dengan berbagai pertimbangan. Prosedur pembuatan pohon tujuan ini adalah :

a. Membuat daftar tujuan perancangan

b. Susun daftar dalam urutan tujuan dari higher-level ke lowerlevel.
c. Gambarkan sebuah diagram pohon tujuan, untuk menunjukkan hubungan- hubungan yang hierarki.

2. Penetapan Fungsi

Dari metode pohon tujuan, dapat dilihat maksud dari permasalahan yang ada mempunyai banyak tingkatan-tingkatan perbedaan yang umum maupun secara rinci. Dengan nyata, tingkat setiap permasalahan memberi arti sangat penting bagi atau oleh perancang. Langkah selanjutnya adalah menetapkan fungsi. Tujuannya adalah untuk menetapkan fungsifungsi yang diperlukan dan batasbatas sistem rancangan produk yang baru. Pada langkah ini digunakan metode analisis fungsional dengan model black box. Metode analisis fungsional menawarkan seperti mempertimbangkan fungsi essensial alat, hasil atau produk atau sistem yang dirancang harus memuaskan, tidak masalah komponen fisik apa yang seharusnya digunakan. Tingkat permasalahan diputuskan dengan mendirikan pembatas di sektor peletakan pengganti yang saling berkaitan dari fungsi.

3. Menyusun Kebutuhan

Setelah fungsi ditetapkan, maka langkah selanjutnya adalah menyusun kebutuhan. Langkah ketiga ini bertujuan untuk membuat spesifikasi pembuatan yang akurat yang perlu bagi desain / rancangan. Metode yang digunakan pada langkah ini adalah Performance Specification Model, yang prosedur pelaksanaannya antara lain :

a. Mempertimbangkan opsi solusi yang beda yang bisa diaplikasikan.

b. Menentukan tingkatan untuk beroperasi.

c. Identifikasi atribut-atribut performansi yang diinginkan.

d. Menentukan kebutuhan performansi untuk setiap atribut.

4. Menetapkan Karakteristik 
Selanjutnya adalah langkah yang disebut penentuan karakteristik, yang bertujuan untuk menentukan target apa yang akan dicapai oleh karakteristik teknik suatu produk sehingga dapat memuaskan kebutuhan-kebutuhan konsumen.

5. Pembangkitan Alternatif

Tujuan dari langkah ini adalah dihasilkannya solusi-solusi rancangan alternatif. Metode yang digunakan adalah metode Morphological Chart. Metode ini mendorong perancang-perancang untuk mengidentifikasi atau mencari kombinasi elemen-elemen yang baru. Tujuan dari metode ini adalah untuk memperluas pencarian bagi solusisolusi baru yang mungkin. Prosedur pelaksanaan metode Morfologi Chart adalah:

a. Buat daftar hal-hal penting atau fungsi-fungsi yang penting untuk produksi. Daftar jangan terlalu panjang, dan harus secara luas mencakup keseluruhan dari fungsi-fungsi yang ada.

b. Untuk tiap hal atau fungsi, buat daftar cara-cara yang dapat dicapai oleh tiap fungsi. Daftar ini dapat mencakup ide-ide baru yang dikenal baik sebagai komponenkomponen atau sub-sub solusi yang ada.

c. Gambarkan sebuah peta yang berisi semua sub-sub solusi yang mungkin.

d. Identifikasi kombinasi sub-sub solusi yang dapat dijalankan.

6. Evaluasi Alternatif

Alternatif-alternatif yang sudah dihasilkan kemudian akan dievaluasi untuk dipilih mana yang menjadi terbaik. Pada langkah ini, digunakan metode Weighted Objective yang bertujuan untuk membandingkan nilai-nilai bantu dari setiap proposal berdasarkan kemungkinan bobot tujuan yang berbeda-beda. Prosedur pelaksanaan metode ini adalah :

a. Daftarkan tujuan perancangan.

b. Golongkan urutan daftar tujuan. c. Berikan hubungan kepentingan pada tujuan.

d. Menetapkan parameter pelaksanaan atau nilai kegunaan untuk masing-masing tujuan.

e. Hitung dan bandingkan hubungan nilai kegunaan perancangan alternatif.

7. Rincian Perbaikan

Banyak pekerjaan perancangan dalam praktek tidak dikaitkan dengan kreasi atas konsep perancangan baru yang radikal, tetapi pembuatan modifikasi untuk mewujudkan rancangan sebuah produk. Modifikasi ini berusaha mengembangkan suatu produk, meningkatkan penampilannya, mengurangi berat, menurunkan biaya, dan mempertinggi daya tariknya. Semua bentuk modifikasi biasanya dapat dibagi ke dalam dua tipe, yaitu modifikasi yang bertujuan meningkatkan nilai produk untuk pembeli dan mengurangi biaya bagi produsen.

\section{METODOLOGI PENELITIAN}

3.1 Obyek Penelitian

Penelitian dilakukan pada pengguna headset dan penutup mata untuk tidur di Yogyakarta dan sekitarnya. Data yang dikaji adalah keluhan bagi para pemakai headset dan penutup mata untuk tidur yang sudah ada di pasaran saat ini. Dengan tujuan penelitian merancang headset dan penutup mata untuk tidur yang lebih baik.

\subsection{Pengumpulan Data}

3.2.1. Data yang diperlukan

Data yang diperlukan untuk mendapatkan informasi yang berguna pada penelitian ini adalah :

1. Data Primer

Data primer yang diperoleh pada penelitian ini adalah data hasil pengamatan langsung di lapangan.

2. Data Sekunder

Data sekunder adalah data yang diperoleh secara tidak langsung tetapi mendukung jalannya penelitian. Data ini berupa informasi-informasi yang diperoleh dengan mempelajari 
literatur-literatur yang berhubungan dengan objek penelitian.

3.2.2 Metode pengumpulan data

1. Penelitian lapangan

Penelitian lapangan yang dilakukan adalah dengan menyebarkan kuesioner kepada 20 mahasiswi yang biasa memakai alat headset dan penutup mata untuk tidur, dengan melakukan wawancara terhadap konsumen dan melakukan pengamatan secara langsung di lapangan.

2. Studi pustaka

Studi pustaka yang dilakukan dalam penelitian ini adalah pemahaman tentang teori perancangan dan pengembangan produk, mencari literatur tentang cara-cara perancangan dan pengembangan alat, dan mempelajari sistematika kerja dari alat headset dan penutup mata untuk tidur yang sudah beredar di pasaran.

\subsection{Langkah-Langkah Perancangan}

Langkah-langkah perancangan menggunakan metode Nigel Cross adalah sebagai berikut :

1. Kuesioner

Kuesioner atau angket adalah pernyataan tertulis yang digunakan untuk memperoleh informasi dari beberapa responden dalam arti laporan tentang pendapat pribadi atau hal-hal yang ia ketahui tentang produk yang sedang diteliti. Dalam tahapan ini akan dilakukan 4 kegiatan lanjutan, yaitu:

a) Uji kecukupan data

Uji kecukupan data pada penelitian kali ini adalah untuk menentukan jumlah sample data yang akan diambil untuk dilakukan proses pengolahan data selanjutnya.

b) Uji keseragaman data

Uji keseragaman data ini digunakan untuk melihat apakah data yang diperoleh dari penyebaran kuesioner dilapangan masih dalam batas kontrol (batas kontrol atas dan batas kontrol bawah).

c) Uji validasi
Uji validasi ini dilakukan untuk menguji kemampuan kuesioner yang akan di sebarkan sehingga benar-benar dapat mengukur hasil yang diperoleh dari penyebaran kuisioner yang kan dilakukan.

d) Uji reliabilitas

Uji reliabilitas dilakukan untuk mengukur sejauh mana hasil dari data yang diperoleh itu dapat dipercaya.

2. Identifikasi Costumer need atau Kuesioner

Identifikasi Costumer need atau kuesioner adalah pengamatan dan pencarian informasi tentang permasalahan dan kebutuhan para konsumen untuk menggunakan alat headset dan penutup mata untuk tidur dengan melakukan penyebaran kuesioner tertutup.

3. Klarifikasi tujuan

Tahap yang pertama adalah mengklasifikasikan tujuan yang ingin dicapai dalam merancang alat penutup telinga tidur yang berisikan tentang kebutuhan konsumen headset dan penutup mata untuk tidur.

4. Penetapan fungsi

Pada tahap penetapan fungsi ini dimulai dengan menyusun fungsi sistem dari alat headset dan penutup telinga untuk tidur model baru, selanjutnya dilakukan analisis fungsifungsi yang diperlukan dan batasanbatasan sistem rancangan alat headset dan penutup mata untuk tidur.

5. Menyusun kebutuhan

Dalam tahap ini mengidentifikasi dan menentukan kebutuhan performansi untuk setiap atribut-atribut yang diperlukan pada saat penyusunan atribut alat headset dan penutup mata untuk tidur.

6. Penentuan karakteristik

Dalam tahap ini dilakukan dengan cara mengidentifikasi keinginan konsumen/pengguna headset dan penutup mata untuk tidur kedalam atribut-atribut produk, menentukan tingkat kepentingan relatif dari atribut-atribut, membuat matrik 
perlawanan antara atribut produk dengan karakteristik produk, selanjutnya mengidentifikasi hubungan antara karakteristik teknis dan tahap akhir yaitu menentukan gambaran target yang ingin dicapai untuk karakteristik perancangan alat headset dan penutup mata untuk tidur.

7. Pembangkitan alternatif

Pembangkitan alternatif dilakukan dengan pertimbangan beberapa alternatif bahan yang akan digunakan untuk pembuatan alat headset dan penutup mata untuk tidur yang digunakan sebagai solusi pembuatan headset dan penutup mata untuk tidur.

8. Evaluasi alternatif

Dalam hal ini yang dilakukan adalah perancangan secara detail dengan menggambar komponen yang diperlukan kedalam Bill of Material (BOM), pembuatan peta proses operasi, gambar komponen yang akan dipakai.

9. Analisis biaya pengembangan

Analisis biaya pengembangan

berkaitan dengan biaya yang

dikeluarkan untuk melakukan produksi dan pengembangan headset dan penutup mata untuk tidur dengan menggunakan perhitungan harga pokok produksi.

\subsection{Analisis Hasil}

1. Analisis Biaya

Pada tahap ini akan dilakukan perhitungan biaya secara rinci yaitu yang mencakup:

a) Biaya komponen dari alat headset dan penutup mata untuk tidur baik itu biaya pembelian maupun biaya pembuatan komponen

b) Biaya perakitan komponen penutup telinga tidur.

c) Menentukan harga pokok penjualan dari alat headset dan penutup mata untuk tidur sehingga siap dipasarkan.

2. Analisis Kepuasan

Pada tahap ini peneliti ingin mendapatkan respon yang baik terhadap alat headset dan penutup mata untuk tidur yang dirancang, berdasarkan dari kuesioner yang diberikan kepada responden konsumen headset dan penutup mata untuk tidur di wilayah Yogyakarta dan sekitarnya.

\subsection{Kesimpulan dan Saran}

Tahap akhir dari proses perancangan adalah membuat kesimpulan mengenai perancangan yang telah dilakukan dan juga memberikan saran atas perancangan tersebut serta referensi untuk penelitian selanjutnya.

\section{PENGOLAHAN DATA DAN ANALISIS HASIL}

Pada perancangan produk dalam penelitian ini, metode yang digunakan yaitu metode Nigel Cross. Perancangan dalam metode ini memiliki 7 tahap. Berikut adalah langkah - langkah yang digunakan dalam perancangan produk dan analisis hasil.

\subsection{Klarifikasi Tujuan}

Klarifikasi tujuan dilakukan untuk menentukan tujuan perancangan dan metode yang digunakan adalah objective tree. Didapatkan dari hasil kuesioner yang berupa keluhan dan keinginan dari konsumen. Alat headset dan penutup mata untuk tidur dengan desain cover yang baru sesuai dengan keinginan konsumen adalah sebagai berikut :

1. Daftar perancangan produk secara keseluruhan antara lain:

a. Alat headset dan penutup mata untuk tidur mempunyai bahan perangkat yang ringan dan kuat.

b. Alat headset dan penutup mata untuk tidur mempunyai ukuran yang ergonomis dan desain yang elegan.

c. Alat headset dan penutup mata untuk tidur mempunyai fungsi dan kualitas yang baik.

2. Urutan daftar tujuan dan sub tujuan produk, yaitu:

a. Atribut Bahan yang berhubungan dengan bahan baku produk.

b. Atribut Pengoperasian yang berhubungan dengan sistem.

c. Atribut desain berhubungan dengan rancangan fisik produk.

Dari data tujuan perancangan yang telah diklasifikasikan maka selanjutnya akan 
dibuat pohon tujuan dari atribut bahan yang dapat dilihat pada Gambar 4.1.

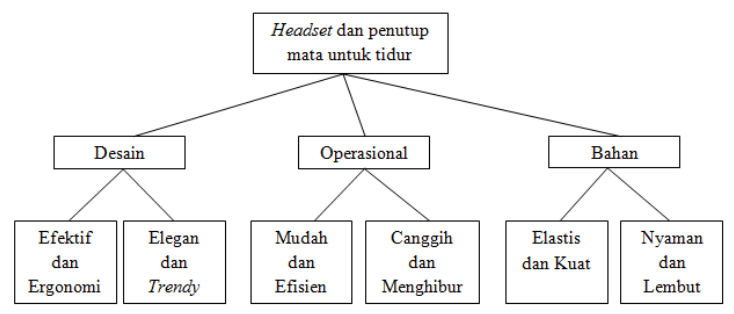

Gambar 4.1. Pohon Tujuan

\subsection{Penetapan Fungsi}

Penetapan fungsi ini bertujuan untuk menetapkan fungsi-fungsi yang diperlukan serta batasan-batasan sistem rancangan produk yang baru. Metode yang digunakan adalah metode analisis fungsi (Analysis Function Method) yang menggambarkan sistem inputoutput dari proses pembuatan headset dan penutup mata untuk tidur dengan prinsip black box seperti pada Gambar 4.2.

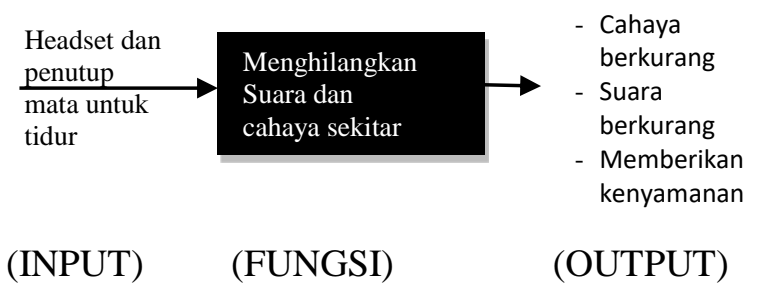

Gambar 4.2. Black box

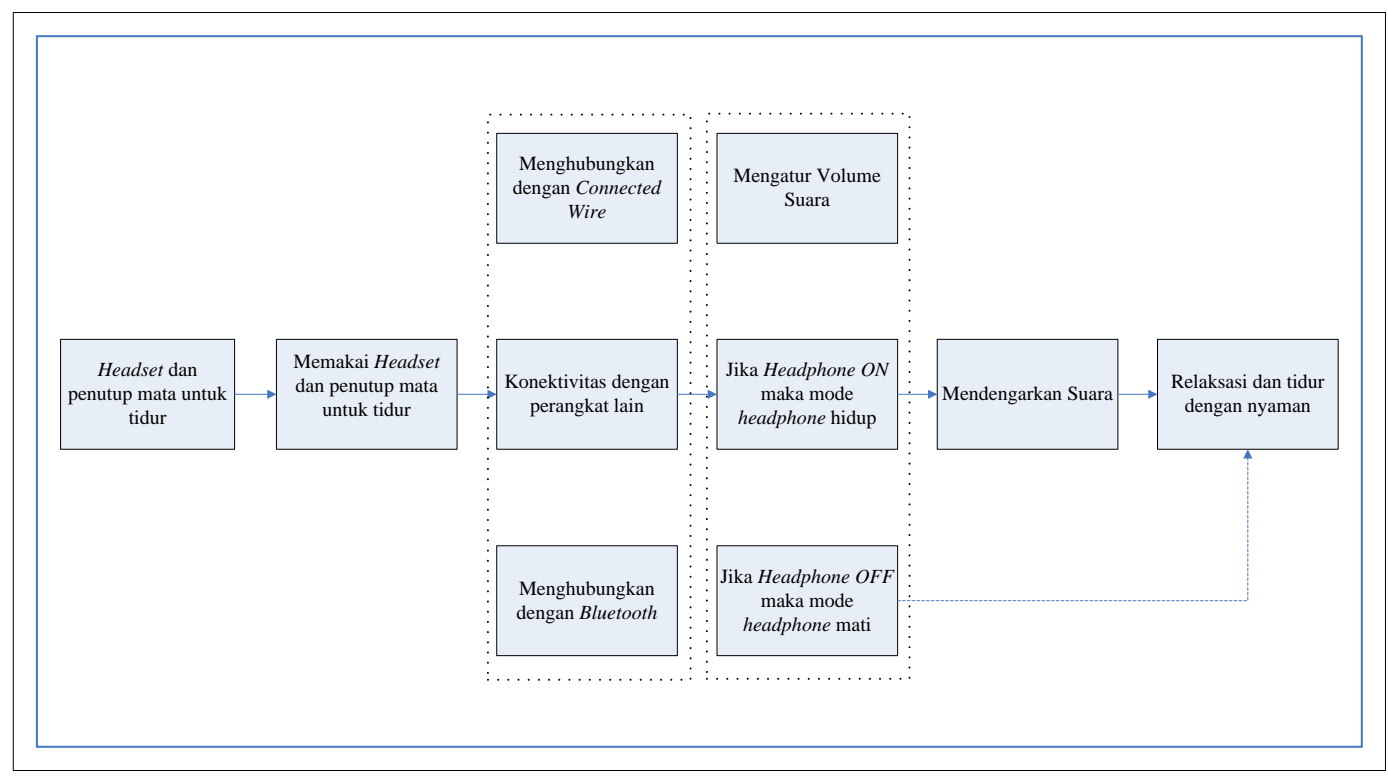

Gambar 4.3. Transparent Box

Jurusan Teknik Industri Fakultas Teknik Industri UPN “Veteran” Yogyakarta 


\subsection{Menyusun Kebutuhan}

Penyusunan kebutuhan adalah suatu cara untuk membandingkan hasil penetapan atribut melalui cara brainstorming dan penetapan atribut melalui hasil rekapitulasi penyebaran kuisioner dengan cara membuat spesifikasi performansi kebutuhan untuk setiap atribut secara lengkap. Spesifikasi performansi kebutuhan dapat dilihat pada Tabel 4.1.

Tabel 4.1 Spesifikasi performansi alat headset dan penutup mata untuk tidur

\begin{tabular}{|l|c|l|c|}
\hline No & $\begin{array}{c}\text { D } \\
\text { atau } \\
\text { W }\end{array}$ & Keinginan & Fitur \\
\hline 1 & D & $\begin{array}{l}\text { Alat headset dan } \\
\text { penutup mata } \\
\text { untuk tidur } \\
\text { memiliki desain } \\
\text { yang bagus }\end{array}$ & Desain \\
\hline 2 & D & $\begin{array}{l}\text { Alat headset dan } \\
\text { penutup mata } \\
\text { untuk tidur yang } \\
\text { lembut dan } \\
\text { nyaman }\end{array}$ & Bahan \\
\hline
\end{tabular}

\begin{tabular}{|l|l|l|c|}
\hline 3 & D & $\begin{array}{l}\text { Alat headset dan } \\
\text { penutup mata } \\
\text { untuk tidur yang } \\
\text { mudah digunakan }\end{array}$ & Operasi \\
\hline 4 & W & $\begin{array}{l}\text { Alat headset dan } \\
\text { penutup mata } \\
\text { untuk tidur } \\
\text { berbahan elastis } \\
\text { dan kuat }\end{array}$ & Bahan \\
\hline 5 & W & $\begin{array}{l}\text { Alat headset dan } \\
\text { penutup mata } \\
\text { untuk tidur bisa } \\
\text { menghibur } \\
\text { konsumen }\end{array}$ & Operasi \\
\hline
\end{tabular}

Keterangan : Demand (D) berasal dari konsumen

Wishes $(\mathrm{W})$ berasal dari desainer

\subsection{Penentuan Karakteristik}

Penentuan karakteristik bertujuan untuk menetukan target apa yang akan dicapai oleh karakteristik teknik suatu produk sehingga dapat memuaskan kebutuhan-kebutuhan konsumen. Berikut adalah jumlah persepsi kepuasan konsumen pada Tabel 4.2.

Tabel 4.2 Jumlah persepsi kepuasan responden

\begin{tabular}{|c|l|c|c|c|c|c|}
\hline \multirow{2}{*}{ No } & \multicolumn{1}{|c|}{ Keinginan konsumen } & \multicolumn{5}{c|}{ Tingkat } \\
\cline { 3 - 8 } & & $\mathbf{1}$ & $\mathbf{2}$ & $\mathbf{3}$ & $\mathbf{4}$ & $\mathbf{5}$ \\
\hline 1 & Bahan cover kain lembut dan kuat & 0 & 0 & 5 & 13 & 2 \\
\hline 2 & Telinga berbahan busa yang nyaman & 0 & 0 & 5 & 14 & 1 \\
\hline 3 & Penutup mata berbahan kain lembut dan kuat & 0 & 0 & 10 & 8 & 2 \\
\hline 4 & Pengoperasian volume yang mudah & 0 & 0 & 6 & 14 & 0 \\
\hline 5 & Memiliki rangka karet yang elastis dan kuat & 0 & 0 & 4 & 13 & 3 \\
\hline 6 & Desain yang elegan dan trendy berukuran sedang & 0 & 0 & 6 & 11 & 3 \\
\hline 7 & Memiliki headphone untuk musik sebelum tidur & 0 & 0 & 8 & 8 & 4 \\
\hline
\end{tabular}

4.5 Pembangkitan Alternatif

Penentuan alternatif rancangan suatu proses perancangan yang berguna untuk membangkitkan alternatif-alternatif yang dapat digunakan untuk mencapai solusi terhadap permasalahan perancangan. Metode yang digunakan adalah menggunakan metode Morphological Chart, seperti pada Tabel 4.3. 
Tabel 4.3 Morphological Chart headset dan penutup mata untuk tidur

\begin{tabular}{|l|c|c|c|c|}
\hline \multirow{2}{*}{\multicolumn{1}{|c|}{ Fitur }} & \multicolumn{4}{c|}{ Solusi } \\
\cline { 2 - 5 } & 1 & 2 & 3 & 4 \\
\hline Desain & Tradisional & Helmet & Bando & Lingkaran \\
\hline Bahan & Kain & Plastik & Karet & Besi \\
\hline Operasi & Tidak pakai & Diputar & Ditekan & Otomatis \\
\hline Ketahanan & Kain & Plastik & Karet & Besi \\
\hline Ukuran & Kecil & Sedang & Besar & Sangat besar \\
\hline
\end{tabular}

\subsection{Evaluasi Alternatif}

Pada tahap ini alternatif-alternatif perancangan produk headset dan penutup mata untuk tidur yang sudah dihasilkan kemudian akan dievaluasi untuk dipilih satu dari tiga alternatif, yang terbaik ini bertujuan agar desainer produk headset dan penutup mata untuk tidur bisa memproduksi produk yang paling baik diantara beberapa alternatif produk yang ada. Berikut adalah hasil pemilihan alternatif produk yang terpilih, bisa dilihat pada Tabel 4.4.

Tabel 4.4 Alternatif Produk yang terpilih

\begin{tabular}{|c|c|}
\hline Alternatif & $\begin{array}{c}\text { Jumlah } \\
\text { responden yang } \\
\text { memilih }\end{array}$ \\
\hline 1 & 18 \\
\hline 2 & 0 \\
\hline 3 & 2 \\
\hline
\end{tabular}

\subsection{Detail Hasil Perancangan}

Detail hasil perancangan adalah suatu upaya untuk memperjelas mengenai bentuk pasti alat, yaitu menggambarkan bentuk alat dan merincikan material penyusun alat. Berikut adalah gambar teknik dari alat,seperti pada Gambar 4.4.

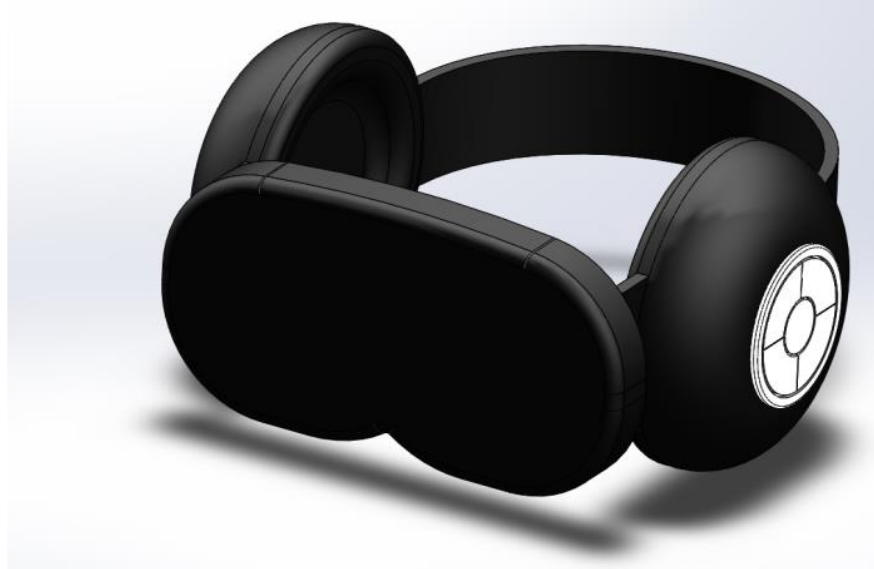

Gambar 4.4 Gambar Teknik Alat 
Adapun gambar dari BOM dengan desain baru dapat dilihat pada Gambar 4.5.

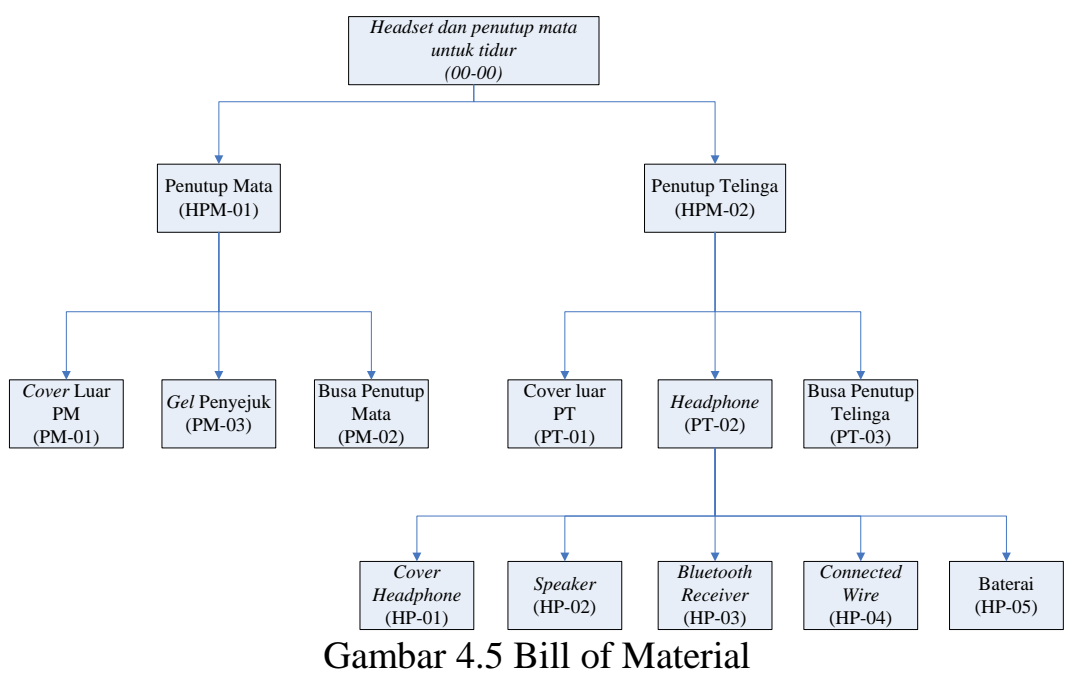

\subsection{Rekayasa Nilai}

Dalam suatu rancangan tidaklah selalu mudah dalam menentukan biaya yang sebenarnya. Metode akuntansi dalam suatu rancangan mungkin tidak cukup untuk menentukan biaya dari setiap item produk yang sudah teridentifikasi. Oleh karena itu dapat digunakan metode biaya perbaikan agar dapat memberikan informasi yang relevan secara detail mengenai biaya yang mungkin digunakan dalam membuat sebuah produk baru dengan desain baru. Langkah-langkah dalam metode analisis biaya antara lain:

4.7.1 Daftar komponen dan identifikasi fungsi produk

Daftar komponen penting dalam headset dan penutup mata untuk tidur secara detail yang digunakan untuk membentuk headset dan penutup mata untuk tidur dapat dilihat pada Tabel 4.5.

Tabel 4.5 Part yang digunakan pada headset dan penutup mata untuk tidur

\begin{tabular}{|l|l|}
\hline \multicolumn{1}{|c|}{ Komponen } & \multicolumn{1}{c|}{ Fungsi } \\
\hline Cover penutup mata & Sebagai lapisan paling luar penutup mata \\
\hline Busa penutup mata & Untuk lapisan dalam penutup mata \\
\hline Gel penyejuk mata & $\begin{array}{l}\text { Sebagai penyejuk mata ketika dimasukkan ke dalam } \\
\text { penutup mata }\end{array}$ \\
\hline Cover penutup telinga & Sebagai lapisan paling luar penutup telinga \\
\hline Busa penutup telinga & Untuk lapisan dalam penutup telinga \\
\hline Cover headphone & $\begin{array}{l}\text { Sebagai wadah untuk meletakkan speaker headphone dan } \\
\text { sebagai pondasi penutup telinga }\end{array}$ \\
\hline Speaker headphone & $\begin{array}{l}\text { Sebagai penghasil suara yang dapat menghibur konsumen } \\
\text { ketika memakai produk }\end{array}$ \\
\hline Bluetooth receiver & $\begin{array}{l}\text { Penerima sinyal } \text { bluetooth yang berfungsi sebagai } \\
\text { penghubung antara headset } \text { dan perangkat lain }\end{array}$ \\
\hline Battery & $\begin{array}{l}\text { Sumber tenaga headset dan penutup mata untuk tidur } \\
\text { apabila menggunakan sambungan dengan bluetooth }\end{array}$ \\
\hline Connected wire & $\begin{array}{l}\text { Penghubung berupa kabel yang berfungsi } \\
\text { menyambungkan headset dan perangkat lain }\end{array}$ \\
\hline
\end{tabular}


4.7.2 Harga pada setiap komponen produk Pada tahapan ini dilakukan pemilihan komponen yang akan digunakan dalam proses perakitan alat atau produksi alat beserta harga dari setiap komponen penyusun alat headset dan penutup mata untuk tidur. Harga yang didapat merupakan hasil survey secara langsung dipasaran. Sehingga nantinya didapat biaya produksi yang pasti dan transparan. Harga dari setiap komponen penyusun alat headset dan penutup mata untuk tidur dapat dilihat pada Tabel 4.6.

Tabel 4.6 Harga komponen - komponen yang digunakan

\begin{tabular}{|c|c|c|c|c|}
\hline Jenis biaya & Komponen & Harga ( Rp) & Jumlah (unit) & Jumlah (Rp) \\
\hline \multirow{9}{*}{ Biaya tetap } & Spandex (1m) & 30.000 & 1 & 30.000 \\
\hline & Katun (1m) & 20.000 & 1 & 20.000 \\
\hline & Busa (1m) & 15.000 & 1 & 15.000 \\
\hline & Busa (1m) & 10.000 & 1 & 10.000 \\
\hline & Busa (1m) & 20.000 & 1 & 20.000 \\
\hline & Karet (1m) & 9.000 & 1 & 9.000 \\
\hline & Solder & 40.000 & 1 & 40.000 \\
\hline & Benang & 2.500 & 1 & 2.500 \\
\hline & Jarum jahit & 500 & 1 & 500 \\
\hline \multirow{6}{*}{ Biaya variabel } & Cooling gel & 20.000 & 1 & 20.000 \\
\hline & Bluetooth receiver & 20.000 & 1 & 20.000 \\
\hline & Battery & 30.000 & 1 & 30.000 \\
\hline & Connected wire & 5.000 & 1 & 5.000 \\
\hline & Headphone & 80.000 & 1 & 80.000 \\
\hline & Lem & 6000 & 1 & 6000 \\
\hline Biaya tenaga kerja & & & & 30.000 \\
\hline Overhead & Listrik & 5.000 & & 5.000 \\
\hline Total & & 313.000 & & 343.000 \\
\hline
\end{tabular}

Dari hasil evaluasi dan survei di lapangan yang dilakukan dapat disimpulkan bahwa biaya tetap yang digunakan dalam pembuatan produk ini adalah sebesar Rp.313.000 termasuk biaya perakitan/biaya tenaga kerja sebesar Rp.30.000, yang telah mencakup biaya bahan yang akan dibuat, biaya pekerja perakitan dan biaya pembelian semua komponen penyusun. Jadi total biaya yang harus dikeluarkan oleh perancang dalam pembuatan produk ini yaitu sebesar Rp.343.000.

Setelah harga pokok penjualan telah didapatkan dari perhitungan diatas, selanjutnya dari pihak perancang menginginkan keuntungan yang akan didapatkan dari produk yang dibuat yaitu sebesar 10\% dengan rincian sebagai berikut: Harga jual $=($ Biaya Pokok Produksi $)+(10 \%$ laba x Biaya pokok produksi) 


$$
\begin{aligned}
& =(343 \cdot 000)+(10 \% \times 343 \cdot 000) \\
& =\text { Rp.343.000,00 }+ \text { Rp. } 34.300,00 \\
& =\text { Rp. 377.300,00 } \approx \text { Rp. } 378 \cdot 000,00
\end{aligned}
$$

Jadi harga jual produk dengan desain yang baru adalah Rp. 378.000,00

\subsection{Analisis Hasil}

Dari pengolahan data maka dapat kita analisis kesesuaian perancangan desain baru headset dan penutup mata untuk tidur, dari 20 responden 17 diantaranya merasa sesuai dengan apa yang diinginkan yaitu headset dan penutup mata untuk tidur desain baru dan 15 diantaranya mau untuk membeli headset dan penutup mata untuk tidur desain baru, kesesuian dari hasil perancangan ini membuat kepuasan untuk para konsumen.

Dengan desain baru headset dan penutup mata untuk tidur desain baru yang menarik, ergonomis dan trendy, konsumen menganggap bahwa alat headset dan penutup mata untuk tidur desain baru ini layak untuk dijual dipasaran menggantikan alat yang lama, ini disebabkan karena alat yang baru, efisien, memiliki hiburan berupa headphone bagi konsumen yang menyukai tidur sambil mendengarkan musik dan ditambah dengan gel yang bisa menghilangkan lingkaran hitam pada mata dan menyejukkan mata.

Selain itu juga alat ini telah di-uji oleh orang yang berkompeten dalam bidang elektronika, yang mana alat baru ini dikatakan sangat inovatif, memiliki nilai jual yang tinggi dan komponen elektrik yang menggabungkan teknologi analog dan bluetooth dalam satu paket headphone. Harga produk pun lumayan terjangkau apabila akan di komersilkan sebagai produk jual, dengan harga Rp.378.000. Harga headset dan penutup mata untuk tidur desain baru tersebut sangatlah murah dibandingkan dengan apa yang sudah ada dipasaran dan fitur yang ada di dalam produk headset dan penutup mata untuk tidur desain baru.

\section{KESIMPULAN DAN SARAN}

5.1. Kesimpulan

Berdasarkan hasil penelitian, maka dapat disimpulkan bahwa alat headset dan penutup mata untuk tidur dengan desain baru telah teruji dan dapat bekerja dengan baik sesuai dengan keinginan dan kebutuhan konsumen. Dari segi harga yang ditawarkan sangat terjangkau dan sebanding dengan fitur tambahan yang ada didalamnya. Setelah dilakukan perancangan ulang alat headset dan penutup mata untuk tidur desain baru, maka biaya yang harus dikeluarkan dalam pembuatannya adalah sebesar Rp. 343.000 rupiah, dan bisa dijual dengan harga Rp. 378.000.

\subsection{Saran}

Berdasarkan hasil penelitian, ada beberapa hal yang bisa menjadi bahan pertimbangan untuk penelitian selanjutnya, pertimbangan tersebut meliputi hal-hal sebagai berikut:

1. Pengembangan alat sebaiknya memperhatikan prinsip-prinsip kerja, nilai tambah alat / inovasi, ergonomi dan kenyamanan konsumen.

3. Penelitian selanjutnya diharapkan dapat menggunakan metode lain untuk perancangan headset dan penutup mata untuk tidur.

4. Pengembangan alat selanjutnya diharapkan bisa menguji efek medis.

5. Peneliti selanjutnya diharapkan dapat mempertimbangkan desain lain untuk pembuatan.

6. Pengembangan alat selanjutnya diharapkan bisa menguji efek medis.

7. Peneliti selanjutnya dapat mempertimbangkan pemilihan warna alat agar dapat menarik minat konsumen. 


\section{DAFTAR PUSTAKA}

Cross, N., 1989, Engineering Design Methods: Strategies For Product Design, Second Edition, John Wiley \& Sons, New York.

Donals, E, Kieso., 2008, Akutansi Intermediate Ed. Ke-12 Jilid 1, Erlangga, Jakarta.

Ferry, H., 2016, Perancangan Alat Pengaman Pada Kendaraan Bermotor, Tugas Akhir, UPN "Veteran", Yogyakarta.

Ginting, R., 2010, Perancangan Produk, Cetakan Pertama, Graha Ilmu, Yogyakarta.

Helmy, 1990, Akuntansi Biaya-Pengantar Untuk Perencanaan dan Pengendalian Biaya Produksi, LPFE, UI, Jakarta.

Khannan, M.S.A., 2010, The application of quality function deployment to increase powder detergent quality, Proceeding 3rd International Seminar on Industrial Engineering and Management (3rd ISIEM), eprints.upnyk.ac.id
Kotler, P., dan Amstrong, G., 1996, Prinsipprinsip Pemasaran, Jilid 2, (Domis Sihombing. AlihBahasa), Erlangga, Jakarta

Kotler, P., dan Armstrong, G., 2004, DasarDasar Pemasaran, Edisi kesembilan, Jilid 1, dialih bahasakan oleh Alexander Sindoro, Jakarta: Indeks.

Kotler, P., dan Keller, K. L., 2009, Manajemen Pemasaran Ed. Ke-13 Jilid 1, Erlangga, Jakarta.

Mulyadi, 2000, Akuntansi Biaya, Edisi Revisi, AMUS, Yogyakarta.

Nurmianto, E., 2004, Ergonomi Konsep Dasar dan Aplikasinya Ed. Ke-2, Guna Widya, Surabaya.

Palgunadi, B., 2008, Desain Produk, Institut Teknik Bandung, Bandung.

Supriyono, 1999, Manajemen Biaya: Suatu Reformasi Pengolahan Bisnis, Penerbit BPFE, Yogyakarta. 